\title{
FORMULASI MINUMAN SINBIOTIK DENGAN PENAMBAHAN PUREE PISANG AMBON (Musa paradisiaca var sapientum) DAN INULIN MENGGUNAKAN INOKULUM Lactobacillus casei
}

\author{
Formulation of Synbiotic Beverage Based on Banana Puree (Musa paradisiaca var sapientum) \\ Using Lactobacillus casei
}

Dewi Desnilasari', Ni Putu Ayu Lestari²

${ }^{1}$ Pusat Pengembangan Teknologi Tepat Guna, Lembaga Ilmu Pengetahuan Indonesia, JL. KS Tubun No.5 Subang 41213
${ }^{2}$ Departemen Ilmu dan Teknologi Pangan, Institut Pertanian Bogor, Gedung Fateta Kampus IPB Darmaga
PO Box 220 Bogor 16680
Email: d_desnilasari@yahoo.com

\begin{abstract}
ABSTRAK
Sinbiotik merupakan kombinasi antara prebiotik dan probiotik. Salah satu komoditas hasil pertanian yang mengandung prebiotik adalah pisang ambon. Penggunaan pisang ambon dan inulin sebagai prebiotik serta $L$. casei sebagai probiotik dapat menghasilkan produk minuman sinbiotik. Untuk diperoleh minuman sinbiotik, diperlukan suatu formulasi minuman yang memanfaatkan pisang ambon menggunakan inoculum $L$. casei sebagai staternya dan penambahan inulin agar diperoleh minuman sinbiotik yang disukai. Penelitian ini bertujuan untuk menemukan formulasi minuman sinbiotik dari puree pisang ambon yang paling disukai. Penelitian ini terbagi menjadi tiga tahap, yang pertama adalah optimasi penggunaan puree pisang ambon dan susu skim dalam minuman sinbiotik menggunakan uji organoleptik, yang kedua adalah optimasi penambahan inulin sebagai prebiotik pada formulasi minuman sinbiotik terbaik yang diperoleh pada tahap pertama melalui uji sensorik serta uji organoleptik dengan melakukan uji rating hedonik, dan tahap ketiga adalah analisis mutu minuman sinbiotik terpilih pada tahap kedua dengan parameter mutu kimia dan mikrobiologi. Minuman sinbiotik terpilih adalah formulasi perbandingan puree pisang dan susu skim 1:1 dengan penambahan inulin 2\%. Hasil analisis mutu minuman sinbiotik dengan kadar air $84,46 \%$, abu $0,75 \%$, protein $2,79 \%$, lemak $0,2 \%$, karbohidrat $11,8 \%$, total BAL 3,6 x $10^{9} \mathrm{cfu} / \mathrm{ml}$, cemaran Coliform dibawah ambang batas yang ditetapkan dan Salmonella negatif.
\end{abstract}

Kata kunci: Pisang ambon, minuman sinbiotik, L. casei

\begin{abstract}
Synbiotic was a combination of prebiotics and probiotics. One of the agricultural commodities that contains prebiotics was "Pisang Ambon". Pisang Ambon and inulin as prebiotics and Lactobacillus casei as a probiotics can produce synbiotic beverages. To obtain synbiotic beverages, it needs a drink formulation that utilizes Pisang Ambon and use inoculum $L$. casei as a stater and adding inulin to obtain preferred synbiotic beverages. The objective of this research was to discover the most preferred formulation synbiotic beverages from puree of Pisang Ambon. This research was divided into three steps, the first step was the optimization of the use puree of Pisang Ambon and skim milk in synbiotic beverages using organoleptic test, the second was the addition of inulin as a prebiotic optimization at the best formulations of synbiotic beverages that obtained in the first step through sensory test and organoleptic test by doing hedonic rating test, and the third step was the analysis of the quality of the best synbiotic beverages in the second stage using parameters of chemical and microbiological quality. The result showed that ratio for skim milk: banana puree were $1: 1$ with $2 \%$ inulin addition was the most preferable synbiotic beverage. Synbiotic beverages contains moisture $84.46 \%$, ash $0.75 \%, 2.79 \%$ protein, $0.2 \%$ fat, $11.8 \%$ carbohydrate, number of LAB $3.6 \times 10^{9} \mathrm{cfu} / \mathrm{ml}$, Coliform below the threshold and negative contamination of Salmonella.
\end{abstract}

Keywords: Pisang ambon, synbiotic beverage, L. casei 


\section{PENDAHULUAN}

Sinbiotik merupakan kombinasi antara probiotik dan prebiotik (Gourbeyre dkk, 2010). Probiotik merupakan mikroorganisme hidup yang ditambahkan pada suatu produk dalam jumlah tertentu dan dapat menyehatkan inangnya. Spesies Lactobacillus dan Bifidobacterium merupakan mikroorganisme yang biasa digunakan sebagai probiotik dalam produk fermentasi (World Gastroenterology Organisation, 2008). Prebiotik merupakan komponen makanan yang tidak dapat dicerna dan mempunyai pengaruh baik terhadap inang dengan memicu aktivitas pertumbuhan selektif bakteri penghuni kolon (Roberfroid, 2005). Salah satu komoditas hasil pertanian yang mengandung prebiotik adalah buah pisang.

Pisang terbagi dalam dua jenis yaitu pisang meja dan pisang olahan. Jenis pisang yang termasuk dalam tipe pisang meja (banana) antara lain Ambon Putih, Ambon Hijau, pisang Mas, pisang Raja, pisang Susu, pisang Badak, pisang Seribu, dan pisang Angling. Jenis pisang meja adalah jenis pisang yang mengandung banyak gula sehingga pada umumnya rasanya lebih manis. Jenis pisang yang tergolong dalam pisang olahan (plantain) antara lain pisang Siam, pisang Nangka, pisang Kapas, pisang Kepok, pisang Gembor, pisang Menggala, dan pisang Tanduk. Jenis pisang olahan ini, kandungan karbohidratnya lebih banyak tersusun atas pati sehingga cocok untuk diolah menjadi tepung pisang (Prabawati dkk, 2009).

Pisang ambon merupakan buah meja yang pemanfaatannya sampai saat ini masih sebatas dimakan langsung. Kandungan vitamin dan mineral esensial pisang sangat bermanfaat bagi kesehatan. Selain itu pisang ambon mempunyai kandungan gula yang tinggi (Sharrock and Lusty, 1999). Senyawa fruktooligosakarida (oligofrucrose) pada pisang sekitar $0,3 \%$ dan bisa dimanfaatkan sebagai sumber prebiotik (Kusharto, 2006). Namun menurut Franck dan De Leenheer (2005) suatu produk sinbiotik dikatakan memiliki sifat fisiologis yang baik jika mengandung inulin sebesar 1-3\%. Oleh karena itu diperlukan penambahan inulin jika ingin membuat sinbiotik dari pisang.

Lactobacillus casei termasuk ke dalam kategori bakteri asam laktat homofermentatif yaitu memecah glukosa terutama menjadi asam laktat kira-kira 90\%. Kemampuan ini lebih tinggi dibandingkan dengan jenis bakteri asam laktat heterofermentatif yang hanya dapat memecah glukosa menjadi asam laktat kurang dari 90\%. Selain itu L. casei dapat menghasilkan sejumlah kecil asam sitrat, asam malat, asam asetat, asam suksinat, asetaldehid, diasetil, dan asetoin yang berperan dalam pembentukan flavor (Varnam dan Sutherland, 1994). L. casei disebut probiotik karena mempunyai manfaat bagi kesehatan diantaranya mendukung respon sistem imun, mendukung kesehatan sel dan meningkatkan bakteri menyehatkan di dalam usus, dapat memodifikasi potensi aktivitas bakteri berbahaya seperti -glukoronidase dan nitroreduktase, dan meningkatkan kesehatan manusia (Takeshi, 2003).

Produk minuman sinbiotik yang dikembangkan saat ini pada umumnya berbasis susu sebagai pembawanya. Kandungan gula tinggi yang dapat dimanfaatkan oleh probiotik dan adanya prebiotik dalam pisang menjadikan pisang memiliki potensi untuk dijadikan sebagai produk sinbiotik. Dilain pihak tidak semua konsumen toleran dengan susu, maka diperlukan produk sinbiotik yang bisa diterima oleh semua kalangan masyarakat. Dengan melihat potensi pisang sebagai bahan yang bisa dimanfaatkan oleh mikroorganisme, maka dibuatlah minuman sinbiotik memanfaatkan pisang ambon dengan inokulum L. casei sebagai staternya. Penelitian ini bertujuan untuk menemukan formulasi minuman sinbiotik dari puree pisang ambon dengan penambahan inulin komersial yang paling disukai dan menguji kualitas mutu produknya secara kimia dan mikrobiologi.

\section{METODE PENELITIAN}

\section{Bahan dan Alat}

Bahan yang digunakan dalam pembuatan minuman sinbiotik pisang pada penelitian ini adalah susu skim, gula pasir, pisang, inulin, dan kultur bakteri Lactobacilus casei serta media yang digunakan untuk analisis mikrobiologi (MRS Broth, MRSA, BSA, HEA, XLDA, SCB, BGLBB, EMBA, dan larutan pengencer $\mathrm{NaCl} 0.85 \%$ ) dan senyawasenyawa kimia untuk uji proksimat. Alat-alat yang digunakan dalam pembuatan pembuatan minuman sinbiotik pisang adalah neraca analitik, homogenizer, lemari pendingin, autoclaf, inkubator, blender, bunsen, pipet, erlenmeyer, water bath, pengaduk, gelas piala, jarum ose, tabung durham, kapas, mikropipet, tips, sudip, desikator, serta alat-alat yang digunakan untuk analisis yaitu $\mathrm{pH}$ meter, oven, gelas ukur, neraca massa, cawan aluminium, cawan porselen, alat destilasi, labu Kjeldal, erlenmeyer, tabung reaksi, dan labu takar.

\section{Lokasi dan Waktu Kegiatan}

Penelitian dilakukan di dua laboratorium, yaitu laboratorium mikrobiologi pangan dan biokimia pangan, Departemen Ilmu dan Teknologi Pangan, Fakultas Teknologi Pertanian, Institut Pertanian Bogor.

\section{Metode}

Pelaksanaan penelitian ini terbagi menjadi 3 tahapan: (1) optimasi penggunaan puree pisang dan susu skim dalam 
minuman sinbiotik untuk mendapatkan perbandingan susu skim dan puree pisang yang tepat secara uji organoleptik. Perbandingan puree pisang dan susu skim yang digunakan adalah $2: 1 ; 1: 1$; dan 1:2. (2) optimasi penambahan inulin sebagai prebiotik pada formulasi minuman sinbiotik terbaik yang diperoleh pada Tahap 1 dengan taraf penambahan inulin $0 \% ; 1 \% ; 2 \%$; dan 3\%. Selanjutnya juga dilakukan uji organoleptik. Uji organoleptik yang dilakukan adalah uji rating hedonik (Meilgard dkk., 2009). Data yang diperoleh diuji menggunakan uji sidik ragam ANOVA dengan uji lanjut Duncan. (3) Analisis mutu terhadap minuman sinbiotik terpilih pada Tahap 2 dengan parameter mutu kimia dan mikrobiologi. Mutu kimia yang diamati meliputi kadar air (AOAC, 1995), kadar abu (AOAC, 1995), kadar protein (Latimer dan Horwitz 2007), kadar lemak (Latimer dan Horwitz, 2007) kadar karbohidrat (metode by difference), pH, TAT (Total Asam Tertitrasi) (AOAC, 1995), TPT (Total Padatan Terlarut) (AOAC, 1995), dan kadar inulin (AOAC, 1995). Analisis mutu mikrobiologi meliputi Total BAL (BSN, 2009), cemaran mikroba koliform (BSN, 2009), dan Salmonella (BSN, 2009). Data yang didapat dianalisis secara deskriptif.

Proses pembuatan minuman sinbiotik pisang dengan cara menyiapkan puree pisang ambon, susu skim dan inulin komersial. Puree pisang Ambon sebagai bahan baku tambahan dalam proses pembuatan minuman sinbiotik dibuat dari pisang Ambon yang matang penuh dilakukan pencucian, pengupasan dan pemanasan selama 7 menit. Pemotongan pisang dilakukan dengan ukuran 0,5-1 cm, kemudian dihancurkan menggunakan waring blender (Ferawati, 2009). Kemudian dilakukan pencampuran dan homogenisasi semua bahan, diikuti dengan pemanasan serta proses pasteurisasi. Setelah dingin atau suam-suam kuku diinokulasikan kultur stater $L$. casei dan dilakukan pengemasan produk. Produk diinkubasi suhu $37^{\circ} \mathrm{C}$ selama 24 jam. Hasil disimpan dalam suhu $5^{\circ} \mathrm{C}$ sebelum dianalisis lebih lanjut.

\section{HASIL DAN PEMBAHASAN}

\section{Optimasi Penggunaan Puree Pisang dan Susu Skim}

Tahap awal penelitian ini adalah optimasi penggunaan puree pisang dan susu skim. Puree pisang yang digunakan adalah puree pisang ambon dengan karakteristik pisang ambon siap makan dengan indeks warna sekitar 6, dan tidak keras saat ditekan. Puree pisang yang ditambahkan dihancurkan menggunakan waring blender (Ferawati, 2009). Perbandingan susu skim dan puree pisang yang ditambahkan adalah 2:1 (A), 1:1 (B): dan 1:2 (C). Hasil uji organoleptik yang dilakukan pada ketiga formulasi tersebut dapat dilihat pada Tabel 1. Uji organoleptik yang dilakukan adalah uji rangking hedonik, dimana setiap panelis akan mengurutkan tingkat kesukaan dengan memberi nilai rangking 1 untuk sampel yang paling disuka, 2 untuk sampel yang dianggap biasa, dan rangking 3 untuk sampel yang paling tidak disukai. Berdasarkan pada uji sidik ragam penggunaan puree pisang dan susu skim pada minuman sinbiotik tidak berbeda nyata pada atribut aroma, tekstur, rasa dan penerimaan keseluruhan pada selang kepercayaan 95\% (Tabel 1).

Tabel 1. Hasil uji organoleptik pengunaan puree pisang dan susu skim pada minuman sinbiotik.

\begin{tabular}{llll}
\hline \multirow{2}{*}{ Parameter } & \multicolumn{3}{c}{$\begin{array}{c}\text { Nilai uji rangking formula } \\
\text { susu skim: puree pisang }\end{array}$} \\
\cline { 2 - 4 } & $2: 1$ & $1: 1$ & $1: 2$ \\
\hline Aroma & $2,06 \mathrm{a}$ & $1,96 \mathrm{a}$ & $1,99 \mathrm{a}$ \\
Tekstur & $1,83 \mathrm{a}$ & $1,99 \mathrm{a}$ & $2,19 \mathrm{a}$ \\
Rasa & $2,13 \mathrm{a}$ & $1,87 \mathrm{a}$ & $2,00 \mathrm{a}$ \\
Penerimaan keseluruhan & $2,14 \mathrm{a}$ & $1,84 \mathrm{a}$ & $2,01 \mathrm{a}$ \\
\hline
\end{tabular}

Keterangan: huruf berbeda di belakang angka menunjukkan beda nyata pada taraf signifikasi $5 \%$

Atribut aroma yang dihasilkan pada semua formula sudah menghasilkan aroma khas minuman sinbiotik dimana telah sesuai dengan ketentuan SNI 01.2981-2009 tentang kualitas yogurt. Hasil uji organoleptik rangking hedonik (Tabel 1) menunjukkan bahwa rata-rata penilaian panelis terhadap atribut aroma yang paling disukai adalah minuman sinbiotik dengan formulasi perbandingan susu skim dan pure 1:1 (skor 1,96). Hal ini menunjukkan penggunaan pisang pada produk sinbiotik meningkatkan penerimaan dalam hal aroma minuman sinbiotik. Menurut hasil survei penelitian Ningsih (2002) tentang pengembangan agribisnis pisang Ambon, menunjukkan bahwa pisang Ambon tergolong jenis pisang yang paling digemari oleh penduduk Indonesia sehingga penambahannya sebagai bahan baku yoghurt akan berdampak baik terhadap penilaian panelis. Pada pisang komponen volatil yang membentuk flavor akhir pada yogurt adalah amil asetat, amil butirat, dan asetaldehid. Amil asetat adalah komponen utama dari bau khas buah pisang. Komponen tersebut terutama terdapat banyak pada pisang matang penuh (Loesecke, 1950).

Atribut tekstur yang dihasilkan pada semua formula produk yoghurt berada pada kisaran kental-semi padat. Tekstur tersebut sesuai dengan persyaratan SNI 01.29812009. Hasil uji organoleptik rangking hedonik pada Tabel 1 memperlihatkan bahwa tingkat kesukaan panelis terhadap tekstur berbanding terbalik dengan semakin banyaknya puree pisang yang ditambahkan. Berdasarkan skor Tabel 1 terlihat bahwa panelis lebih menyukai tekstur yang padat dan lembut dibanding dengan tekstur yang kasar yaitu formula dengan 
penambahan puree pisang paling sedikit. Penambahan puree pisang yang lebih sedikit menghasilkan tekstur yang lebih bagus karena penambahan puree pisang dapat menyebabkan berkurangnya homogenitas adonan. Puree pisang yang ditambahkan memiliki ukuran granula yang lebih besar dibandingkan dengan susu skim sehingga menimbulkan kesan kasar saat di lidah. Selain itu komponen protein yang terdapat pada susu skim mengalami penggumpalan yang disebut curd yang teksturnya padat dan lembut, sedangkan puree pisang tidak mengalami penggumpalan. Oleh karena itulah semakin sedikit puree pisang yang ditambahkan maka tekstur sinbiotik menjadi semakin padat dan lembut, dimana sampel ini paling disukai oleh panelis.

Atribut rasa yang terbentuk pada minuman sinbiotik dipengaruhi oleh beberapa faktor, diantaranya kemampuan bakteri yang digunakan sebagai kultur untuk melakukan pemecahan laktosa. Bakteri L. casei mampu memecah laktosa menjadi asam laktat dan sejumlah kecil asam sitrat, malat, asetat, suksinat, asetaldehid, diasetil, dan asetoin (Varnam dan Sutherland, 1994). Selain pemecahan laktosa, pemecahan protein oleh bakteri juga menghasilkan cita rasa atau flavor yang enak pada yoghurt (Tamime dan Robinson, 1989). Selain itu rasa juga dipengaruhi oleh bahan baku yang digunakan dalam pembuatan yoghurt. Berdasarkan hasil penelitian yang dilakukan oleh Kuntarso (2007), penambahan buah-buahan dapat membuat penerimaan konsumen terhadap produk yoghurt semakin meningkat atau mempunyai tingkat kesukaan yang yang lebih tinggi jika dibanding dengan yoghurt tanpa penambahan buah (yoghurt plain).

Hasil uji organoleptik rangking hedonik pada Tabel 1 menunjukkan formula dengan penambahan susu skim:puree pisang sebesar 1:1 memiliki skor penilaian terendah yaitu sebesar 1,87 yang berarti paling disukai oleh konsumen dibanding dua formula yang lainnya. Penambahan puree pisang yang tepat dapat menghasilkan rasa yang disukai karena penambahan puree pisang yang berlebihan dapat menyebabkan timbulnya rasa sepat. Menurut Loesecke (1950) rasa sepat pada pisang disebabkan karena kandungan tanin yang dapat menggumpalkan protein sehingga terjadi penyamakan pada bagian mukosa rongga mulut.

Secara umum nilai terkecil ada pada perbandingan susu skim:puree pisang 1:1 yaitu atribut aroma 1,96, rasa 1,87, dan penerimaan keseluruhan 1,84 yang berarti produk tersebut paling disukai. Oleh karena itu formula yang terpilih adalah formula dengan perbandingan susu skim dan puree pisang 1:1. Hal ini menyimpulkan bahwa panelis menyukai penambahan puree pisang pada produk dengan konsentrasi yang tepat. Oleh karena itu formula yang terpilih sebagai formula yang digunakan pada tahap selanjutnya adalah formula dengan penambahan susu skim:puree pisang sebesar $1: 1$.

\section{Optimasi Penambahan Inulin pada Minuman Sinbiotik Pisang}

Penambahan inulin pada minuman sinbiotik pisang bertujuan sebagai penambah sumber prebiotik selain dari puree pisang. Penelitian ini menggunakan formula terpilih tahap I dengan penambahan puree pisang:susu skim sebanyak 1:1. Pada tahap ini dibuat produk dengan 4 formula yaitu sampel tanpa penambahan inulin, dengan penambahan inulin $1 \%$, $2 \%$, dan 3\%. Penambahan inulin dilakukan sebelum proses pasteurisasi agar menghindari terjadi kontaminasi dari inulin. Hal ini juga didukung bahwa menurut Roberfroid (2005), inulin tahan jika dipanaskan hingga proses pasteurisasi.

Keempat sampel tersebut selanjutnya akan dinilai tingkat kesukaannya oleh panelis menggunakan uji rating hedonik dengan parameter atribut aroma, tekstur, rasa, dan penerimaan keseluruhan. Berdasarkan hasil uji rating hedonik, diperoleh hasil seperti yang disajikan pada Tabel 2 .

Tabel 2. Hasil uji organoleptik penambahan inulin pada minuman sinbiotik pisang.

\begin{tabular}{lcccc}
\hline & \multicolumn{4}{c}{$\begin{array}{c}\text { Skor uji rating hedonik formula dengan } \\
\text { penambahan inulin* }\end{array}$} \\
\cline { 2 - 5 } Parameter & Inulin 0\% & Inulin 1\% & Inulin 2\% & Inulin 3\% \\
\cline { 2 - 5 } & $4,60 \mathrm{a}$ & $4,16 \mathrm{a}$ & $4,31 \mathrm{a}$ & $4,37 \mathrm{a}$ \\
Aroma & $4,69 \mathrm{a}$ & $4,31 \mathrm{a}$ & $4,74 \mathrm{a}$ & $4,46 \mathrm{a}$ \\
Tekstur & $4,71 \mathrm{a}$ & $4,34 \mathrm{a}$ & $4,76 \mathrm{a}$ & $4,80 \mathrm{a}$ \\
Rasa & $4,59 \mathrm{a}$ & $4,27 \mathrm{a}$ & $4,69 \mathrm{a}$ & $4,67 \mathrm{a}$ \\
Penerimaan & & & & \\
keseluruhan & &
\end{tabular}

Keterangan : *skor 1-7 (1 : sangat tidak suka, 7 : sangat suka) huruf berbeda di belakang angka menunjukkan beda nyata pada taraf signifikasi $5 \%$

Penambahan inulin memberikan pengaruh yang tidak berbeda nyata terhadap aroma, tekstur, dan rasa minuman sinbiotik pada selang kepercayaan 95\%. Hal ini berarti penambahan inulin tidak mengubah aroma, rasa, dan tekstur dari produk hingga penambahan sebanyak 3\%. Hal ini sesuai dengan teori yang mengatakan bahwa salah satu karakeristik inulin adalah tidak berbau dan tidak berasa (Roberfroid, 2005).

Tabel 2 menunjukkan skor kesukaan panelis terhadap atribut keseluruhan sinbiotik adalah 4,27-4,69. Penambahan inulin pada konsentrasi 0-3\% pada produk tidak berpengaruh nyata terhadap keseluruhan atribut sinbiotik pada selang kepercayaan 95\%. Hal tersebut didukung oleh pernyataan Roberfroid (2005) yang menyatakan bahwa inulin mempunyai karakter tidak berasa, tidak berbau, dan berwarna putih sehingga jika ditambahkan pada produk yoghurt tidak 
memberi pengaruh yang signifikan secara organoleptik. Penambahan inulin dalam jumlah 1-3\% ke dalam produk yoghurt lebih dimanfaatkan sifat fisiologisnya yaitu sebagai sumber prebiotik (Franck dan De Leenheer, 2005). Skor penilaian yang berkisar antara 4,27-4,69 (netral hingga agak suka) menunjukkan bahwa sinbiotik yang dihasilkan masih dapat diterima oleh konsumen.

Semua atribut yang diujikan yaitu aroma, tekstur, rasa, dan keseluruhan mendapat penilaian dari panelis dengan nilai diantara 4 sampai 5 yang artinya menurut panelis, sinbiotik yang dihasilkan bernilai netral hingga agak suka. Selain itu berdasarkan hasil analisis sidik ragam, untuk semua atribut yang diujikan seluruhnya tidak berbeda nyata pada selang kepercayaan 95\%. Hal ini menunjukkan bahwa penambahan inulin tidak memberikan pengaruh negatif terhadap organoleptik produk. Oleh karena itu, semua formula sinbiotik dengan penambahan inulin $(1,2$, dan 3\%) dapat dipilih sebagai formula terpilih tahap II.

Formula terpilih adalah formula dengan penambahan inulin 2\%. Hal ini disebabkan formula dengan penambahan inulin 2\% memiliki kandungan prebiotik yang tepat dan ekonomis. Produk dikatakan berprebiotik jika kadar prebiotik minimal adalah 1\% (Franck dan De Leenheer, 2005). Selain itu nilai atribut rasa, tekstur, aroma dan penerimaan keseluruhan untuk penambahan $2 \%$ dari nilai uji organoleptik lebih besar dibanding dengan penambahan inulin 1\%. Sedangkan formula penambahan inulin 3\% mempunyai biaya produksi yang lebih tinggi dibanding formula yang lainnya. Oleh karena itu dipilih produk dengan penambahan inulin sebanyak $2 \%$. Penambahan inulin sebanyak $2 \%$ sudah dapat memberikan efek prebiotik yang baik. Hal ini didukung oleh hasil penelitian Sadek dkk. (2004), yang menyatakan bahwa penambahan $2 \%$ inulin ke dalam yoghurt dapat meningkatkan viabilitas dari bakteri asam laktat. Selain itu Boeni dan Pourahmad (2012) menemukan bahwa pembuatan yogurt sinbiotik menggunakan $L$. casei dan L. acidophillus dengan penambahan inulin $2 \%$ meningkatkan penilaian organoleptik produk.

\section{Analisis Mutu terhadap Minuman Sinbiotik Terpilih}

Pengujian mutu minuman sinbiotik yang dilakukan adalah analisis mutu kimia dan mutu mikrobiologi. Analisis mutu kimia meliputi pH, TAT, total padatan, kadar inulin dan uji proksimat (kadar air, abu, lemak, protein, dan karbohidrat). Sedangkan analisis mutu mikrobiologi meliputi jumlah total BAL produk serta cemaran mikrobanya yaitu koliform dan Salmonella. Hasil uji tersebut kemudian dibandingkan dengan SNI yoghurt tahun 2009 dikarenakan belum adanya SNI minuman sinbiotik. Hasil analisis mutu kimia minuman sinbiotik seperti pada tabel 3 .
Tabel 3. Tabel hasil analisis mutu kimia minuman sinbiotik formula terpilih (berdasarkan $b / b$ )

\begin{tabular}{lc}
\hline \multicolumn{1}{c}{ Komposisi } & Nilai \\
\hline Kadar Air (\%) & 84,46 \\
Kadar Abu (\%) & 0,75 \\
Kadar Protein (\%) & 2,79 \\
Kadar Lemak (\%) & 0,20 \\
Kadar Karbohidrat (\%) & 11,80 \\
pH (derajat keasaman) & 4,30 \\
TAT (\% asam laktat) & 0,74 \\
TPT & 15,36 \\
Kadar inulin (g/100g) & 3,88 \\
\hline
\end{tabular}

Produk sinbiotik yang dihasilkan memiliki $\mathrm{pH}$ 4,3. Nilai ini sudah memenuhi $\mathrm{pH}$ yoghurt yang baik. Menurut Tamime dan Robinson (1989) yoghurt yang baik memiliki $\mathrm{pH}$ 3,8-4,6, bahkan Jay (2000) memberikan kisaran $\mathrm{pH}$ yoghurt yang lebih luas lagi yaitu antara 3,65-4,40. Penelitian tentang yoghurt dengan penambahan buah yang dilakukan oleh Kuntarso (2007) juga mempunyai kisaran $\mathrm{pH}$ yang sama yaitu 4,3, begitu pula dengan hasil penelitian Aryana dan McGrew (2007) yang membuat yoghurt dengan bakteri L. casei dan penambahan berbagai jenis inulin yang mempunyai $\mathrm{pH}$ antara 4,32-4,60.

Nilai $\mathrm{pH}$ yang rendah yaitu $<4,5$ sudah dapat menggumpalkan protein kasein pada susu dan membentuk tekstur yang baik. Hasil penelitian membuktikan bahwa sinbiotik yang dihasilkan dengan nilai $\mathrm{pH}$ 4,3 sudah mampu menggumpalkan kasein dan membentuk tekstur yang baik, selainitudengantingkatkeasamantersebutsudahmenghasilkan flavor khas yaitu aroma asam susu fermentasi. Nilai pH yang cukup rendah pada produk yoghurt memiliki kemungkinan yang sangat kecil timbulnya pertumbuhan bakteri patogen. Selain itu, yoghurt dengan $\mathrm{pH}$ 4,3 dapat mempertahankan viabilitas dari bakteri probiotik (Lankaputhra, 1996).

Pengukuran total asam tertitrasi (TAT) didasarkan atas komponen asam yang ada, dan nilai tersebut sebanding dengan jumlah asam laktat. Berdasarkan Tabel 3 dapat dilihat bahwa rata-rata total asam tertitrasi sampel terpilih minuman sinbiotik adalah sebesar $0,74 \%$. Nilai ini menurut Silvia (2002) sudah cukup dalam menghasilkan tekstur yang lembut serta flavor asam yang cukup kuat. Selain itu hasil tersebut menurut SNI 01.2981-2009 tentang standar mutu yoghurt masih mempunyai nilai yang baik yaitu termasuk dalam kisaran $0,5-2 \%(b / b)$.

Berdasarkan hasil analisis, minuman sinbiotik mempunyai total padatan sebesar $15,36 \%$. Hasil ini sesuai dengan literatur menurut Tamime dan Robinson (1989) 
yang menyatakan bahwa yoghurt yang baik memiliki nilai total padatan berkisar antara 14-18\%. Nilai ini juga sudah memenuhi persyaratan SNI 01.2981-2009, bahwa total padatan produk yoghurt minimal $8.2 \%$. Total padatan yang tinggi pada produk minuman sinbiotik diperoleh karena bahan baku yang digunakan adalah susu skim. Menurut Tamime dan Robinson (1989) penambahan susu skim bubuk dapat meningkatkan kandungan protein, selain sebagai sumber laktosa bagi kehidupan kultur bakteri asam laktat. Kandungan protein yang semakin meningkat akan menaikkan total padatan susu karena penggumpalan kasein yang terjadi semakin banyak. Penggumpalan kasein ini yang kemudian akan mempengaruhi kekentalan susu fermentasi dan meningkatkan total padatannya. Selain itu, penambahan pisang tidak dalam bentuk ekstrak melainkan dalam bentuk puree juga dapat menambah jumlah total padatan pada produk yoghurt.

Penentuan kadar inulin pada produk minuman sinbiotik penting dilakukan untuk mengetahui jumlah prebiotik yang terkandung dalam produk agar memenuhi persyaratan suatu produk dapat dikatakan berprebiotik. Penambahan inulin sebagai sumber prebiotik pada produk fermentasi menurut Frank (2005) yaitu sebesar 1-3\% per kemasannya. Berdasarkan hasil uji organoleptik yang dilakukan pada tahap II, formula yoghurt yang terpilih adalah yoghurt dengan penambahan $2 \%$ inulin. Hasil pengujian inulin menggunakan HPLC menunjukkan bahwa kadar inulin pada produk akhir yoghurt sinbiotik adalah sebesar 3,88g/100g. Jumlah ini sudah memenuhi persyaratan yoghurt berprebiotik. Namun jumlah ini sedikit lebih tinggi dibandingkan dengan jumlah inulin komersial yang ditambahkan pada awal proses pengolahan produk yaitu $2 \mathrm{~g} / 100 \mathrm{~g}$. Hal ini disebabkan karena kadar inulin yang terdapat pada produk akhir tidak hanya berasal dari penambahan inulin komersial pada produk, tetapi juga berasal dari bahan baku pisang yang digunakan.

Minuman sinbiotik yang terpilih juga di uji proksimat bertujuan untuk mengetahui komponen kimia pada suatu bahan pangan. Hasil analisis proksimat yang dihasilkan memberi gambaran secara umum tentang nilai gizi dari produk minuman sinbiotik. SNI 01.2981-2009 tentang yoghurt menyebutkan bahwa kadar abu, kadar protein, dan kadar lemak berturut-turut adalah maksimal 1,0\%, minimal $2,7 \%$, dan $<0,5 \%$. Berdasarkan hasil uji proksimat pada Tabel 3 terlihat bahwa kadar abu, kadar protein, dan kadar lemak pada produk yoghurt sinbiotik yang dihasilkan telah memenuhi persyaratan. Kadar air pada produk berdasarkan hasil analisis proksimat adalah sebesar 84,46\%. Nilai kadar air ini sudah tergolong baik untuk produk yoghurt walaupun kadar air bukan termasuk salah satu persyaratan produk yoghurt menurut SNI (2009). Nilai kadar air produk yoghurt yang tergolong baik, dapat dilihat dari sudah tercukupinya nilai total padatan dari produk yoghurt yang dihasilkan dimana dengan kadar air $84,46 \%$, total padatannya sudah memenuhi persyaratan SNI yaitu sebesar $15,54 \%$ dan menghasilkan tekstur yoghurt yang padat.

Kadar abu pada produk pangan dipengaruhi oleh kandungan mineral di dalam produk. Kandungan mineral yang terkandung dalam produk yoghurt dapat berasal dari bahan baku pisang dan susu skim. Buckle dkk. (1987) menyatakan bahwa kandungan mineral pada susu skim sekitar $8 \%$. Artinya penambahan susu skim sebanyak $10 \%$ akan menyumbang mineral sebanyak $0,8 \%$ pada produk yoghurt. Hasil ini tidak jauh berbeda dengan hasil analisis proksimat yang tertera pada Tabel 3 yaitu sebesar $0,75 \%$.

Kadar protein pada produk adalah sebesar 2,79\%. Kadar protein pada minuman sinbiotik banyak disumbangkan oleh susu skim sebagai bahan bakunya. Akan tetapi nilai ini sedikit lebih kecil dibandingkan dengan nilai kadar protein pada susu skim yaitu sebesar 3,7\% (Buckle dkk., 1987). Kadar protein pada yoghurt umumnya tidak terdapat perubahan yang signifikan hanya saja terjadi peningkatan daya cerna karena terjadi penguraian protein menjadi unit-unit yang sederhana.

Hasil uji proksimat kadar lemak pada minuman sinbiotik yaitu sebesar $0,2 \%$. Kadar lemak yang terkandung pada produk tergantung pada bahan baku yang digunakan dalam pembuatan minuman sinbiotik. Kadar lemak yang diperoleh sangat rendah karena minuman sinbiotik dibuat menggunakan susu skim yang rendah lemak dan puree pisang yang juga mengandung lemak yang sangat kecil. Menurut Buckle dkk. (1987) susu skim hanya mengandung sekitar $0,1 \%$ lemak, sehingga jika minuman sinbiotik yang dibuat hanya menggunakan susu skim akan memiliki kadar lemak yang rendah pula. Data ini dapat digunakan untuk mengklaim bahwa produk yang dihasilkan digolongkan sebagai minuman sinbiotik non-fat (kadar lemak $<0,5 \%$ ).

Hasil analisis proksimat yang terakhir adalah kadar karbohidrat. Berdasarkan Tabel 3 dapat dilihat kadar karbohidratnya sebesar 11,8\%. Nilai kadar karbohidrat ini sangat tergantung pada bahan-bahan lain yang ditambahkan pada yoghurt. Pada penelitian ini, sumber karbohidrat dapat berasal dari susu skim, selain itu bahan baku pisang sebagai buah yang ditambahkan ke dalam minuman sinbiotik tentunya berperan dalam meningkatkan kadar karbohidrat pada produk.

\section{Analisis Mikrobiologi Minuman Sinbiotik Terpilih}

Uji mikrobiologi minuman sinbiotik dilakukan untuk melihat mutu produk secara mikrobiologi. Kandungan probiotik dalam minuman sinbiotik diamati untuk mengetahui kestabilan L. casei dalam minuman sinbiotik. Pengamatan terhadap total bakteri asam laktat (BAL) dari segi kuantitas dan viabilitas dilakukan selama 14 hari pada produk yang 


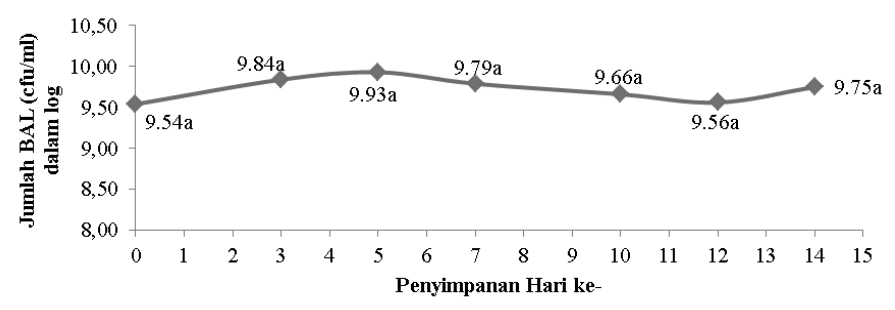

Gambar 1. Grafik jumlah total BAL selama 14 hari

disimpan di suhu dingin dan pengamatan dilakukan setiap 3-4 hari sekali.

Hasil perhitungan total bakteri asam laktat yang terdapat dalam produk minuman sinbiotik formulasi terpilih

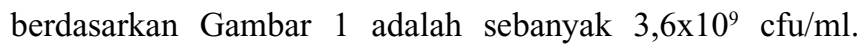
Jumlah tersebut sudah memenuhi persyaratan suatu produk dapat dikatakan probiotik menurut FAO/WHO (2002) yaitu $10^{6}-10^{8} \mathrm{cfu} / \mathrm{ml}$. Jumlah total BAL berdasarkan hasil uji sidik ragam pada gambar 1 memperlihatkan nilai tidak berbeda nyata pada masa penyimpanan 0-14 hari. Hasil ini sesuai dengan penelitian Boeni dan Pourahmad (2012) bahwa penambahan $2 \%$ inulin pada yogurt sinbiotik dengan $L$. casei dan L. acidophillus yang disimpan pada suhu dingin dapat meningkatkan viabilitas probiotik. Menurut Buckle dkk. (1987), faktor utama yang mempengaruhi pertumbuhan mikroorganisme salah satunya adalah suhu. Pada penyimpanan suhu dingin, terdapat hambatan aktivitas mikroorganisme berupa temperatur yang rendah. Hal ini menyebabkan aktivitas bakteri tidak optimal dan pertumbuhannya menjadi lambat atau bahkan terhambat. Hal serupa juga dikemukakan oleh Aryana dan McGrew (2007) yang melihat pertumbuhan L. casei pada yogurt yang diberi inulin dan disimpan pada suhu $4^{\circ} \mathrm{C}$, menyatakan bahwa selama penyimpanan $L$. casei mengalami penurunan yang tidak signifikan kurang dari 1 siklus log selama 2 minggu.

Penelitian Oberman (1985) menunjukkan bahwa jumlah BAL pada yoghurt yang disimpan dalam suhu dingin mengalami perubahan jumlah yang tidak signifikan, yaitu masih kurang dari satu siklus log, hal ini menunjukkan bahwa Lactobacillus casei memiliki ketahanan yang baik pada kondisi asam. Menurut Yamazaki dkk. (1973) dikutip dalam Lee dan Wong (1998), Lactobacillus dan Bifidobacteria memiliki ketahanan yang baik pada $\mathrm{pH}$ yang rendah, begitu pula menurut Salminen dan Wright (1998), Lactobacillus casei dapat bertahan lebih lama dalam susu fermentasi. Hasil penelitian yang sama juga didapat oleh Setiawan (2010) yang mendapatkan hasil bahwa bakteri L. casei yang ditumbuhkan pada produk dadih yang disimpan pada suhu dingin mengalami peningkatan yang tidak signifikan hingga hari ke-7 dan memiliki rata-rata jumlah total bakteri asam laktat sebanyak $2,2 \times 10^{11} \mathrm{cfu} / \mathrm{ml}$.
Menurut Uji total koliform dan uji Salmonella perlu untuk dilakukan dalam minuman sinbiotik. Uji total koliform dilakukan untuk mengetahui keberadaan mikroba koliform atau indikator sanitasi pada suatu produk. Jenis bakteri koliform ini yaitu bakteri Esherichia coli dan Enterobacter yang pada minuman sinbiotik dapat berasal dari susu, air, dan buah yang digunakan sebagai bahan baku pembuatan produk. Uji Salmonella dilakukan secara kualitatif pada produk yang disimpan pada suhu dingin dengan melakukan tahap enrichment dan tahap seleksi. Tujuan dilakukannya uji ini adalah untuk mengetahui apakah produk yoghurt sinbiotik yang dihasilkan mengandung Salmonella atau tidak.

Berikut data hasil pengujian koliform dan Salmonella pada produk yoghurt hari ke-0 dan hari ke-14 dapat dilihat pada Tabel 4.

Tabel 4. Tabel hasil uji koliform dan Salmonella minuman sinbiotik

\begin{tabular}{ccc}
\hline Hari ke- & $\begin{array}{c}\text { Koliform } \\
\text { Hasil kuantitatif } \\
(\mathrm{MPN} / \mathrm{g})\end{array}$ & $\begin{array}{c}\text { Salmonella } \\
\text { Hasil kualitatif }\end{array}$ \\
\hline 0 & $<3,0$ & Negatif/25g \\
14 & $<3,0$ & Negatif/25g \\
\hline
\end{tabular}

Menurut hasil tersebut maka dapat dikatakan minuman sinbiotik dengan penambahan puree pisang dan inulin ini memenuhi persyaratan SNI 01.2981-2009. Produk yang telah diolah dengan cara yang baik dan benar, memiliki kemungkinan kontaminasi oleh bakteri koliform yang rendah. Dengan adanya blansir pada bahan baku pisang dan proses pasteurisasi pada susu sudah dapat mematikan bakteri koliform. Hal ini didukung oleh pernyataan menurut Tamime dan Robinson (1989) yang menyatakan bahwa grup koliform tidak tahan pada $\mathrm{pH}$ rendah, penyimpanan suhu rendah dan tidak tahan dengan adanya zat hasil metabolisme BAL seperti zat antimikroba dan asam laktat sehingga adanya bakteri koliform pada yoghurt sangat kecil.

Produk yoghurt yang dihasilkan tidak mengandung bakteri Salmonella karena produk ini telah diolah dengan baik dan benar, salah satunya penerapan proses pasteurisasi. Salmonella tidak tahan terhadap panas sehingga dapat mati pada suhu pasteurisasi. Menurut Jay (2000) Salmonella dapat dihancurkan pada proses pemanggangan pada suhu $71,1^{\circ} \mathrm{C}$ dan menurut Lund (2000) dengan suhu pasteurisasi tersebut mampu menurunkan jumlah sel hidup Salmonella sebanyak $10^{5}$ sel. Selain itu produk-produk yoghurt mempunyai $\mathrm{pH}$ yang rendah sehingga mikroba patogen tidak dapat tumbuh, serta terbentuknya asam-asam organik dan zat antimikroba yang berasal dari bakteri probiotik dapat membunuh mikroba-mikroba patogen (Tamime dan Robinson, 1989). 
Produk yoghurt yang dihasilkan tidak mengandung bakteri indikator sanitasi koliform dan Salmonella yang menandakan bahwa proses pasteurisasi yang dilakukan sudah cukup untuk membunuh kedua jenis bakteri tersebut. Selain itu, tidak terjadi kontaminasi kembali setelah proses pengolahan sehingga produk tidak terkontaminasi bakteri indikator sanitasi hingga diakhir penyimpanan suhu dingin selama 14 hari.

\section{KESIMPULAN}

Pemanfaatan pisang ambon menjadi minuman sinbiotik meningkatkan nilai guna pisang dan menghasilkan produk alternatif pangan fungsional baru yang disukai. Minuman sinbiotik terpilih adalah formulasi perbandingan puree pisang dan susu skim 1:1 dengan penambahan inulin $2 \%$. Hasil analisis mutu minuman sinbiotik dengan kadar air $84,46 \%$, kadar abu $0,75 \%$, kadar protein $2,79 \%$, kadar lemak $0,2 \%$, kadar karbohidrat $11,8 \%$, total BAL 3,6 x $10^{9} \mathrm{cfu} / \mathrm{ml}$, cemaran Coliform di bawah ambang batas yang ditetapkan dan Salmonella negatif.

\section{DAFTAR PUSTAKA}

Aryana, K.J. dan McGrew, P. (2007). Quality attributes of yogurt with Lactobacillus casei and various prebiotics. LWT - Food Science and Technology 40: 1808-1814.

AOAC (Analysis of The Association of Analytical Chemists) (1995). Official Methods of Analysis of The Association of Analytical Chemists. Washington D.C.

Boeni, S. dan Pourahmad, R. (2012). Use of inulin and probiotic lactobacilli in synbiotic yogurt production. Annals of Biological Research 3(7): 3486-3491.

Badan Standarisasi Nasional (2009). SNI 01.1298-2009 Yoghurt. Badan Standarisasi Nasional, Jakarta.

Buckle, K.A., Edwards, R.A, Fleet, G.H. dan Wooton (1987). Ilmu Pangan, Terjemahan H. Purnomo dan Adiono. Universitas Indonesia Press, Jakarta.

Franck, A. dan De Leenher, L. (2005). Inulin Dalam: Steinbuchel A, dan Rhee, S.K. (ed). Polysaccharides and Polyamides in The Food Industry. Volume 1. WILEY-VCH, Weinheim.

Ferawati (2009). Formulasi dan Pembuatan Banana Bars Berbahan Dasar Tepung Kedelai, Terigu, Singkong, dan Pisang Sebagai Alternatif Pangan Darurat. Skripsi. Fakultas Teknologi Pertanian. Institut Pertanian Bogor, Bogor.
Gourbeyre, P., Denery, S. dan Bodinier, M. (2010). Probiotics, Prebiotics, and Synbiotics: impact on the gut immune system and allergic reactions. Journal of Leokocyte Biology 89(5): 685-695.

Jay, J.M. (2000). Modern Food Microbiology. $6^{\text {th }}$ Edition. Aspen Publisher, Inc, Gaithersburg, Maryland.

Kuntarso, A. (2007). Pengembangan Teknologi Pembuatan Low-Fatfruity Bio-Yoghurt (Lo-Bio F). Skripsi. Fakultas Pertanian. Institut Pertanian Bogor, Bogor.

Kusharto, M.C. 2006). Serat makanan dan peranannya bagi kesehatan. Jurnal Gizi dan Pangan 1(2): 45-54.

Lankaputhra, W.E.V, Shah, N.P. dan Britz, M.L. (1996). Survival of bifidobacteria during refrigerated storage in the presence of acid ang hydrogen peroxide. Milchwissenschaft 51: 65-70.

Latimer, G.W. dan Horwitz, W. (2007). Official Methods of Analysis of The Association of Official Analytical Chemist International. Ed ke-18.: AOAC International, Washington DC.

Lee dan Wong (1998). Stability of lactic acid bacteria in fermented milk. Dalam: Salminen, S. dan A.Von Wright (eds). Lactic Acid Bacteria: Microbiology An Functional Aspects. $2^{\text {nd }}$ Edition. Marcel Dekker Inc, New York.

Lund, M. (2000). The Microbiological Safety and Quality of Food. Aspen Publishers Inc, Maryland.

Loesecke, H.W.V. (1950). Bananas. Interscience Publisher Inc, New York.

Meilgaard, M., Civille, G.V., dan Thomas, B.C. (1999). Sensory Evaluation Techniques. CRC Press LLC, USA.

Ningsih, Y. (2002). Analisis Kelayakan Investasi Pengembangan Agribisnis Pisang Ambon Lokal di Kecamatan Baso, Kabupaten Agam, Propinsi Sumatera Barat. Tesis. Manajemen Bisnis. Intitut Pertanian Bogor, Bogor.

Oberman, H. (1985). Fermented milk. Dalam: Nakazawa, Y. dan Hosono, A. (ed.) Microbiology of Fermented Milk, Challenges for Health Science. Elsevier Applied Science Publishers Ltd, London.

Poedjiadi, A. (1994). Dasar-dasar Biokimia. Universitas Indonesia Press, Jakarta.

Prabawati, S., Suyanti dan Setyabudi, D.A. (2009). Teknologi Pasca Panen dan Pengolahan Buah Pisang. Balai Besar Penelitian dan Pengembangan Pascapanen Pertanian, Bogor. 
Roberfroid, M. (2005). Inulin-type Fructans: Functional Food Ingredients. CRC Press, Florida.

Sadek, Z.I., El-Shafei, K. dan Murad, H.A. (2004). Utilization of xanthan gum and inulin as prebiotics for lactic acid bacteria. Disampaikan dalam $9^{\text {th }}$ Egyptian Conference for Dairy Science and Technology, Cairo, Egypt, October 9-11, 2004, 9 (Research Papers 1) (pp. 269283). Egyptian Society of Dairy Science, Cairo, Egypt.

Salminen, S. dan Wright, A.T. (1998). Lactic Acid Bacteria: Microbiology and Functional Aspects. $2^{\text {nd }}$ edition. Marcel Dekker Inc, New York.

Setiawan, B. (2010). Produksi Dadih Probiotik Menggunakan Lactobacillus casei, Lactobacillus plantarum, Bifidobacterium longum serta Pengaruhnya selama Penyimpanan. Skripsi. Fakultas Teknologi Pertanian. Institut Pertanian Bogor, Bogor.

Sharrock, S. dan Lusty, C. (1999). Nutritive Value of Banana. International Network for the Improvement of Banana and Plantain Annual Report. 28-31.
Takeshi, M. (2003). Health properties of milk fermented with Lactobacillus casei strain Shirota (LcS). Dalam: Farnworth, E. R. (Ed). Handbook of Fermented Functionl Foods (hal. 145-175). CRC Press LLC, Boca Raton, FL.

Tamime, A.Y. dan Robinson, R.K. (1989). Yoghurt Science and Technology. Pergamon Press, Ltd, Canada.

Varnam, A.H. dan Sutherland, P. (1994). Milk and Milk Products: Technology Chemistry and Microbiology. Chapman and Hall, London.

Winarno, F.G. (1997). Kimia Pangan dan Gizi. PT. Gramedia Pustaka Utama, Jakarta.

World Gastroenterology Organisation (2008). World Gastroenterology Organisation Practice Guideline: Prebiotics and Prebiotics. Milwaukee: World Gastroenterology Organisation, United State America. 